\title{
KAPELA SV. JERONIMA U ŠTRIGOVI- HODOČASTILIŠTE ZA SPAS DUŠE FRIDRIKA CELJSKOG
}

Nakon tiskanja prijevoda knjige Josipa Bedekovića pitanje rodnog mjesta svetog Jeronima ponovo je postala tema koja zaokuplja povjesničare. Dok se rješenje uglavnom traži u geografskim položajima rimske Panonije i Dalmacije, mi ćemo se baviti srednjovjekovnom problematikom i pokušati odgovoriti na pitanje dolaska samog štovanja u Štrigovu. ${ }^{1}$

\section{UVOD}

Potraga za rodnim mjestom sv. Jeronima popularna je tema koja povjesničare i zaljubljenike u povijest zaokuplja već stoljećima, a mjesta diljem Hrvatske, Bosne i Hercegovine, Slovenije i Mađarske vole se kititi tradicijom antičkog Stridona. ${ }^{2}$ Jedno od tih mjesta je i Štrigova u Međimurju, na samom sjeveru Hrvatske, blizu granice sa Slovenijom i nedaleko od granice s Mađarskom, gdje njegovanje te tradicije nalazimo još u kasnom srednjem vijeku. Kroz ovaj ćemo

1 Rad je nastao uz financijsku potporu Filzofskog fakulteta Sveučilišta u Zagrebu.

2 Za kratki pregled lokacija naknadno povezivanih s antičkim Stridonom vidi: Josip FLORSCHÜTZ, „Stridon i Zrin", Vjesnik Arheološkog muzeja u Zagrebu Vol 6 Br1, Zagreb, 1902., str. 87 - 98; Frane BULIĆ, Stridon (Grahovo Polje u Bosni) rodno mjesto svetog Jeronima. Rasprava povjesno geografska, Sarajevo, 1920., str. 5 - 10; Marko MARULIĆ, „Životopis sv. Jeronima prezbitera koji je sastavio Marko Marulić, uz dodatak čudesa koja o njemu pripovijeda Ćiril, biskup nazaretski, prikazanih u sažetijem obliku“, Latinska manja djela II, Split, 2011. 
rad analizirati Štrigovu kroz ranije srednjovjekovne izvore, detektirati trenutak u kojem se počela štovati kao rodno mjesto sv. Jeronima te konačno, pokušati dokučiti koji su točno uzroci utjecali na to i kako se to reflektiralo na stoljeća koja su dolazila. Brojne studije bavile su se kultom sv. Jeronima među Hrvatima i Slavenima ${ }^{3}$ u srednjem vijeku, ${ }^{4}$ kao i kultom sv. Jeronima općenito, ${ }^{5}$ a ipak nam ni jedna od njih ne može ponuditi odgovor o istoj pojavi u Štrigovi. Povjesničari koji su se do sada posvetili toj temi uglavnom su se bavili pitanjima i granicama rimske Panonije, ${ }^{6}$ kao i eventualnim smještajem rimskog Stridona na području današnjeg Međimurja, ${ }^{7}$ bez da je itko postavio pitanje: kako i kada se javilo štovanje svetog Jeronima u Štrigovi. ${ }^{8}$ Mi se antičkim Stridonom, kazivanjima samog Jeronima i eventualnim granicama Panonije i Dalmacije $u$ to vrijeme ne mislimo baviti, već nas isključivo zanima dolazak kulta svetog Jeronima u Štrigovu. Kako bismo riješili zagonetku, potrebno je osim samog kulta svetog Jeronima prije svega promotriti političke okolnosti iz sredine 15. stoljeća, politiku feudalnih gospodara Međimurja (Celjski) i njihovu povezanost s drugim visokim plemstvom i mogućim utjecajima. Kako bismo se približili odgovoru, analizirat ćemo isprave vezane uz Štrigovu u srednjem vijeku, povijest obitelji Celjski (posebno dio vezan za Međimurje), te na koncu veze Celjskih i visokog plemstva na čijim je posjedima zabilježeno štovanje svetog Jeronima. Osim literature, poslužit ćemo se i brojnim izvorima, kako dokumentarnim, tako i narativnim i kartografskim, a zanimljive nam tragove donose i ostaci graditeljske baštine druge polovice 15. stoljeća.

3 Bez da ulazimo u ikakvu etnogenezu, pitanje etniciteta i identiteta, napominjemo da u kontekstu štovanja sv. Jeronima možemo govoriti o oba termina, iako u problematici vezanoj uz ovaj rad zapravo predstavlja istu skupinu stanovništva.

4 Ines IVIĆ, „Jerome Comes Home: The Cult of Saint Jerome in Late Medieval Dalmatia“, Hungarian Historical Review 5, no. 3, Budimpešta, 2016., str. 1-27 i u članku navedena literatura.

5 John V.A. FINE, „The Slavic Saint Jerome“, Harvard Ukrainian Studies 22, Harvard, 1998., str. 101 113; Julia VERKHOLANSTEV, The Slavic Letters of st. Jerome. The History of the Legend and Its Legacy, or, How the Translator of the Vulgate Became an Apostle of the Slavs, DeKalb, 2014.

6 Izuzev rada Ivana Srše u kojem se donekle dotaknulo stvarne problematike i ponudila neka razmišljanja: Ivan SRŠA, „Crtice o međimurskom srednjovjekovlju“, Kaj: časopis za književnost, umjetnost $i$ kulturu 50, Zagreb, 2017., str. 87 - 89.

7 BULIĆ, Stridon; Josip BEDEKOVIĆ, Natale solum magni ecclesiae doctoris sancti Hieronymi in ruderibus Stridonis occultatum, Bečko Novo Mjesto, 1752.; godine 2017. knjiga je prevedena i na hrvatski, iz čega je i proizašao znanstveni skup koji bio i povod novom buđenju kulta svetog Jeronima. Zbornik skupa prema najavi izlazi 2018. godine. Autori koji su pokušali odgovoriti na pitanje o rodnom mjestu sv. Jeronima uglavnom su se bavili isključivo pitanjem antičkog položaja Stridona i mogućnošću da je to Štrigova, analizirajući uglavnom Bulića i Bedekovića.

8 Već smo napomenuli izuzetak: SRŠA, Crtice, str. 89 - 93.; U članku su brojne stvari ostale nejasne, primjerice, prema autoru je štovanje svetog Jeronima u Štrigovi započelo još krajem 14. ili najkasnije početkom 15. stoljeća, iako za to nema apsolutno nikakvih izvora. 


\section{UKRATKO O KULTU SV. JERONIMA}

O štovanju svetog Jeronima u srednjovjekovnim hrvatskim zemljama napisana je brojna literatura. ${ }^{9}$ Hrvatski su krajevi u toj jeronimskoj tradiciji prije svega prepoznati kao specifični zbog borbe senjskih i krčkih biskupa za služenje liturgije na narodnom jeziku i korištenje glagoljice u pismu. ${ }^{10}$ Godina 1248. ., kada papa Innocent obavještava senjskog biskupa da je svjestan korištenja glagoljice i narodnog jezika i to odobrava, ${ }^{11}$ možda je i najvažniji trenutak čitavog procesa rasta i širenja jeronimske tradicije srednjovjekovnim hrvatskim zemljama. Jeronim, kao netko tko je preveo Bibliju na pučki latinski jezik, u tim je interpretacijama čak postao začetnikom glagoljice, Slavenom ili u nekim tumačenjima i Hrvatom. Primjerice u Petrisovom zborniku naziva se Hrvatinom. ${ }^{12}$ Kako je Jeronim jedan od velikih crkvenih otaca, njime se spomenuto slavensko, odnosno hrvatsko svećenstvo izuzetno ponosilo i njegov je kult dodatno jačan i širen kroz samostane i župe glagoljaša, ali i ostalog svećenstva. Takva su tumačenja naravno bila potpomognuta i onodobnim shvaćanjima prema kojima su Hrvati na svojim područjima autohtoni, ${ }^{13}$ a kako je Jeronim u svojem De viris ilustribus objasnio da se njegov Stridon nalazi na granici Panonije i Dalmacije, velika je vjerojatnost da je to upravo bilo na ondašnjim hrvatskim prostorima, što je kasnije i rezultiralo silnim raspravama. Posebno je štovan u Dalmaciji, Kvarneru i Istri. Ono što je za ovaj rad bitno, kult svetog Jeronima na tim prostorima nije slabio do sredine 15. stoljeća. ${ }^{14}$ Na kraju krajeva, još i Bedeković u 18. stoljeću piše o Jeronimu kao začetniku glagoljice, prije svete braće.

9 Vidi: IVIĆ, Jerome Comes Home; FINE, Slavic Saint; Vanda KRAFT SOIĆ, „OTPIS INOCENTA IV. SENJSKOM BISKUPU (1248.) POD PATRONATOM SV. JERONIMA / II. Povijesni usud glagoljice i začetci jeronimske tradicije", Croatica Christiana periodica, Vol 40 No 78, Zagreb, 2016. str. 17 - 37; Wilhelm LETTENBAUER, „Zur entstehung des glagolitischen alphabets“, Slovo: časopis Staroslavenskoga instituta u Zagrebu, No 3, Zagreb, 1953., str. 35 - 50. i u člancima navedena literatura.

10 FINE, The Slavic Saint, str. 103.

11 Za preciznu interpretaciju papina pisma vidi: Vanda KRAFT SOIĆ, „OTPIS INOCENTA IV. SENJSKOM BISKUPU (1248.) POD PATRONATOM SV. JERONIMA I. Senjski privilegij iz godine 1248.“, Croatica Christiana periodica, Vol 40 No 77, Zagreb, 2016. str. 1 - 23.

12 Vesna BADURINA STIPČEVIĆ, „Legenda o svetom Jeronimu u hrvatskoglagoljskom Petrisovu zborniku“, Radovi : Radovi Zavoda za hrvatsku povijest Filozofskoga fakulteta Sveučilišta u Zagrebu, Vol. 47 No. 1, Zagreb, 2016., str. 344.

13 KRAFT SOIĆ, OTPIS INOCENTA IV. SENJSKOM BISKUPU 2, str. 21.

14 O popularnosti Jeronima i širenju kulta od strane hrvatsko - dalmatinskih svećenika vidi: Luka ŠPOLJARIĆ, „Venecijanski skjavoni i povijesno-liturgijska knjižica u čast sv. Jeronima llira iz 1498. godine“ Colloquia Maruliana ..., 27. (27.), Split, 2018., str. 43-71. 


\section{ŠTRIGOVA U SREDNJEM VIJEKU DO 1447. GODINE}

Štrigova u srednjem vijeku predstavlja jedno od dva najvažnija središta, odnosno, uz Čakovec jednu od dvije utvrde koje su obilježile čitavo područje između Mure i Drave. Dok se u kasnom srednjem vijeku nalazi kao trgovište (oppidum), ${ }^{15}$ u 13 . i 14 . stoljeću je nalazimo isključivo kao utvrdu (castrum). ${ }^{16}$ Za početak ćemo promotriti isprave vezane uz Štrigovu do kritičnog trenutka godine 1447., odnosno gradnje kapele i hodočastilišta sv. Jeronima u Štrigovi. Za podrijetlo imena Štrigove, ali i mjesta sličnog imena (Esztergom, Střehom, Strzegom) postoje dvije glavne znanstveno prihvaćene teorije. Jedna je da je ime bugarsko - turskog podrijetla i da označava zanatliju koji izrađuje kožne oklope, a druga je da je slavenskog podrijetla i označava kožara, odnosno osobu koja se bavi preprodajom i obradom kože. ${ }^{17}$ Kao utvrdu, pod nazivom Strigo (spominju se dvije utvrde istog naziva), nalazimo je već 1271., u vrijeme građanskih ratova u Ugarskoj, ${ }^{18}$ kada je, čini se, pripala pod nadležnost štajerskih kapetana. ${ }^{19}$ To je čini prvom spominjanom utvrdom u Međimurju u službenim dokumentima, čak starijom i od Čakovca, što i ne čudi. Prostor Međimurja tada je granični prostor između Svetog Rimskog Carstva i Ugarskog Kraljevstva, a upravo je Štrigova najisturenija utvrda na tom području, pa je i strateška važnost velika. Nakon što je 1328. prostor međurječja Mure i Drave vraćen ugarskom kralju, Štrigovu opet, kao utvrdu, nalazimo u ispravi godine 1334., kada je posjed označen utvrdama Čakovec i Štrigova predmet u razmjeni s utvrdom Komarnicom (Komarom) između kralja i Donka, sina Dominika. ${ }^{20}$ Devet godine kasnije, odnosno godine 1343., ponovo se spominju u poslovima vezanim za Donka utvrde Čakovec i Štrigova,

15 O pojavi velikog broja trgovišta u 15. stoljeću vidi: István PETROVICS, „King Mathias and the Towns of Realm", Analele Banatului , s.n., Arheologie - istorie, XXI, 2013, str. 283 - 294.

16 Brojne isprave vezane uz Štrigovu navodi i: Csánki DEZSŐ, Magyarország történelmi földrajza a Hunyadiak korában, 3.kötet, Zalävarmegye, Várai és erösségei, S(z)trigo - online izdanje: https:// www.arcanum.hu/hu/online-kiadvanyok/Csanki-csanki-dezso-magyarorszag-tortenelmi-foldrajza-ahunyadiak-koraban-1/iii-kotet-62BB/zalavarmegye-62DC/varai-es-erossegei-6300/, 6. siječnja 2018.; Anđela FRANČIĆ, „Ojkonim Štrigova kroz stoljeća“, Folia onomastica Croatica, vol , br 21, Zagreb, 2012., str. $37-58$.

17 Lajos KISS, Földrajzi nevek etimológiai szótára, Budimpešta, 1980., str. 209.; Određena razmišljanja o podrijetlu imena nudi i Ivan Srša u već spomenutom članku, no ne vidimo ni jedan argument zbog kojeg bi etimologiju imena temeljili na eventualnom stanju Međimurja u antici, kad nemamo apsolutno nikakvih izvora za Štrigovu u to vrijeme.

18 O Međimurju u drugoj polovici 13. stoljeća vidi: Zoran TURK, „Srednjovjekovno plemstvo Međimurja“, Radovi Zavoda za znanstveni rad HAZU Varaždin, br 28, 2017., str. 322 - 326.

19 Georgius FEJÉR, Codex diplomaticus Hungariae ecclesiasticus ac civilis, 5, 1., Budimpešta 1829, str. 116.

20 Ivan KUKULJEVIĆ SAKCINSKI, Jura Regni Croatiae, Dalmatiae et Slavoniae, Zagreb, 1861., str. 105. 
odnosno Sturgou. ${ }^{21}$ Sredinom istog stoljeća, godine 1350., kralj Ludovik Veliki Anžuvinac daje isti posjed Stjepanu Lackoviću, ${ }^{22}$ a godinu kasnije kraljica Elizabeta istu darovnicu potvrđuje. ${ }^{23}$ I u tom slučaju se Štrigova navodi kao utvrda, ovaj put Oztrogo. I krajem tog 14. stoljeća Štrigova se ponovo navodi u izvoru, ovaj puta kao utvrda Ztrigov, koju kralj skupa s Čakovcem i pripadajućim posjedima daje sinovima bana Konye ${ }^{24}$ u zamjenu za neka njihova dobra. ${ }^{25} \mathrm{U}$ ispravi kralja Sigismunda iz godine 1415., u kojoj se spominju neka dobra Hermana Celjskog, spominje se i utvrda Štrigova, ovaj put kao Trygaw. ${ }^{26}$ Zanimljivo, čini se da je Štrigova kroz 15. stoljeće gubila na značenju i da prestaje biti utvrda koja obilježava čitavo vlastelinstvo. Godine 1437. u sporu Fridrika Celjskog i Zagrebačke biskupije oko desetine u Međimurju nalazimo vlastelinstvo označeno kao dominium castri Schakatornn (Čakovec) inter fluvios Muram i Drawam. ${ }^{27}$ Slično je i godine 1441., kada vlastelinstvo također označava samo s Čakovcem, ${ }^{28}$ te 1443 . godine ${ }^{29}$ lako ovo nisu sve isprave, jasno je da Štrigova ima dugi kontinuitet pojavljivanja u izvorima. Zanimljivo je naglasiti da se u gotovo dva stoljeća (od prvog spominjanja pa do godine 1447.) nikad u kontekst Štrigove ne dovodi sv. Jeronim. Istina, riječ je o izvorima u kojima Štrigova uglavnom obilježava vlastelinstvo. Ipak, kad bi tradicija svetog Jeronima u Međimurju bila zastupana i prije sredine 15. stoljeća, sigurni smo da bi se ona našla i u izvorima, koji, kao što vidimo, nisu toliko rijetki kao što se često smatra. Međimurjem su gospodarile redom najvažnije obitelji Kraljevstva i prije Celjskih, a osim toga, od godine 1376. Međimurje, upravo uz blagoslov erdeljskih vojvoda Lackovića, nastanjuju i pavlini. Ni jedan poznati izvor vezan uz bilo koga od njih ne spominje štovanje svetog Jeronima. Ono što je još važno, ni jednom se ne navodi ni kao Stridon, Strido ili Strydo.

21 Nagy IMRE: Anjoukori okmánytár. Codex diplomaticus Hungaricus Andegavensis. IV. (1340-1346), Budapest, 1884., str. 339.

22 Tadija SMIČIKLAS, Codex diplomaticus regni Croatiae, Dalmatiae et Slavoniae. Diplomatički zbornik kraljevine Hrvatske, Dalmacije i Slavonije, sv. XI, Zagreb, 1913., str. 619, dok. 477 [za čitavu seriju dalje: $C D]$.

23 CD XII, str. 11-12, dok. 9.

24 Riječ je o obitelji Sečenji, više o njima vidi: TURK, Plemstvo, str. 332 - 336.

25 CD XVIII., str. 216, dok. 143.

26 DIPLOMATIKAI LEVÉLTÁR (dalje: DL), 10330.

27 Andrija LUKINOVIĆ, Povijesni spomenici Zagrebačke biskupije sv. VI(1421 - 1440.), Zagreb 1994., str. 469, dok. 459.

28 Andrija LUKINOVIĆ, Povijesni spomenici Zagrebačke biskupije sv. VII (1441. - 1465.), Zagreb, 2004., str. 15, dok. 22.

29 Isto, str. 37, dok. 41. 


\section{GROFOVI CELJSKI U MEĐIMURJU}

lako Celjski ulaze u Međimurje tek godine 1405., kada im posjed kralj zalaže za 48.000 zlatnih forinti, ${ }^{30}$ glavnina se te priče odvila gotovo desetljeće prije, tijekom bitke na Nikopolju. Dok su dotadašnji gospodari Međimurja, Lackovići (Lackfyi), u dijelu ondašnje elite optuženi za izdaju i prerano povlačenje s bojnog polja, Herman Celjski je kralju Sigismundu Luksemburškom spasio život i time trajno ušao u njegovu milost. Lackovići su si dodatno zagorčali život spletkama i pokušajima dovođenja novog kralja za vrijeme Sigismundova odsustva. Sve je kulminiralo na Krvavom saboru u Križevcima 1397. kada Lackovići gube posjede i živote. Celjski su i prije Međimurja zadobili posjede u Slavoniji i Zagorju, te time postali i magnati Ugarskog Kraljevstva. Ako i izuzmemo kapelu svetog Jeronima, razdoblje Celjskih ostavilo je izuzetno bogatu graditeljsku baštinu, kako na području Međimurja, tako i ostatka njihove državine. ${ }^{31}$ Za njihovo razdoblje, u kojem se kao donator javlja i Jan Vitovac, ${ }^{32}$ možemo vezati niz gotičkih svetišta na području Međimurja. ${ }^{33}$

\section{VEZA CELJSKIH I FRANKAPANA}

Iako je gradnju uvelike poticao i Herman Celjski, on za našu priču nije toliko bitan koliko njegov sin Fridrik. Poznata je epizoda iz povijesti, koja je kroz stoljeća dobila i romantičnu notu, a danas postaje i turistička atrakcija Hrvatskog zagorja, o njegovoj nesretnoj ljubavi s Veronikom Desinić. ${ }^{34} U$ stvarnosti je riječ o daleko većoj traumi. Celjski su izuzetno pažljivo birali ženidbene partnere i to je predstavljalo važan dio njihove strategije gomilanja posjeda i moći. ${ }^{35}$ Tako je i za Fridrika izabrana Elizabeta Frankapan, jedina kći Stjepana Frankapana. ${ }^{36}$ Kako je određeni miraz iznosio 40.000 forinti, kao zalog ostavljeni su posjedi Trsat, Bakar, Bribir i pola otoka Krka. Time su te obitelji i stupile u trajnu vezu, a Elizabeta je ro-

30 Literatura o Celjskima je izuzetno bogata, za kratki pregled predlažemo: Robert KURELIĆ, „Pregled povijesti grofova Celjskih", Historijski zbornik 59, Zagreb, 2006., str. 201-216. i u članku navedena literatura.

31 Vidi: Zdenko BALOG, Graditeljska baština Hermana Celjskog i njezini odrazi u 15. stoljeću u zapadnoj Slavoniji, doktorska disertacija, Filozofaski fakultet u Zagrebu, Zagreb, 2012.

32 Njemu Katarina Celjska pokušava prodati vlastelinstvo nakon smrti Ulrika, međutim, Matija Korvin joj posjed na temelju ošastnog prava uzima.

33 Isto, str. 147 - 151; O gotičkim svetištima Međimurja vidi i: Anđela HORVAT, Spomenici arhitekture i likovnih umjetnosti u Međimurju, Čakovec, 2010., str. 48 - 77.

34 KURELIĆ, Pregled povijesti, str. 212.

35 Isto.

36 Isto. 
dila Fridriku i sina Ulrika. Tragedija se desila godine 1422., kada je Elizabeta pronađena mrtva, a Fridrik ženi lokalnu plemkinju Veroniku Desinić. Jasno je da su Fridrik i Veronika odmah postali glavni osumnjičeni, a Frankapani u bijesu silom zauzimaju sva založena imanja. Herman Celjski bio je svjestan katastrofe koju je njegov sin prouzročio i kako bi pokušao sprati ljagu, Veroniku daje utopiti, a sina zatočiti! ${ }^{37}$ Fridrik Celjski time trajno gubi svaki kredibilitet. Čak i kad mu mlađi brat umire, a otac se prisiljen pomiriti s njime, on nikad nije na čelu obitelji, već ta uloga pripada njegovu sinu Ulriku. ${ }^{38}$ Moguće da je ta obiteljska trauma ostala i oslikana na freskama kapele sv. Ivana u Ivaniću Miljanskom. ${ }^{39}$ Doživotno označen svojim nedjelom, osramoćen od oca, Fridrik se sasvim očekivano posvetio vjeri i gradnji crkava i hodočastilišta, ne bi li makar osigurao mir na drugom svijetu. ${ }^{40}$ Ulrik s druge strane mora čistiti za vlastititim ocem i ponovo uspostaviti veze $s$ Frankapanima. Robert Kurelić je posljednjih godina upozorio na veze Frankapana i Celjskih koje traju sve do izumiranja obitelji, a koje do sada nisu u tom svjetlu razmatrane. Tako je u Nürnberškoj kronici zabilježeno da su trojica Frankapana, Sigismund, Dujam i Martin označeni kao saveznici Ulrika Celjskog u „prvom markgrofskom ratu“, ${ }^{41}$ i očito je da su članovi obitelji Frankapana bili tijesno vezani uz njegovu politiku u brojnim segmentima. Čini se da je jedan od njih bio i svjedok Ulrikove smrti u Beogradu! ${ }^{42}$ Time je neupitno dokazano da su veze Celjskih i Frankapana u vrijeme gradnje hodočastilišta u Štrigovi itekako žive i jake, što nam je vrlo važno za traženje potencijalnog odgovora na pitanje dolaska tradicije u Štrigovu. Ne treba naravno naglašavati da Frankapani dolaze iz samog srca jeronimske tradicije u Hrvatskoj i da na svojim posjedima imaju brojne popove glagoljaše, uključujući i one posjede koji su kao miraz pripali Celjskima. Konačno, upravo je u graditeljskoj baštini Celjskih sačuvan i mogući ostatak veze s Frankapanima. Na arheološkom nalazištu crkve sv. Mihovila u Mihovljanu pronađeno je u kamenu isklesano gotičko slovo $m$ s grbom (tri zvijezde) Celjskih. Isto takvo gotičko $m$ nalazi se i u crkvi sv. Martina u Svetom Martinu na Muri. Povjesničari

37 Isto.

38 Fridrik naravno nije u potpunosti izgubio moć, on raspolaže velikim imetkom i obnaša ugledne dužnosti, ali ipak nikad nije povratio ugled koji je uživao prije. Potencijalno je važno za ovu priču da u vrijeme gradnje kapele u Štrigovi obnaša sa sinom dužnost bana Slavonije.

39 BALOG, Graditeljska baština, str. $124-125$.

40 Isto, str. $32-33$.

41 Robert KURELIĆ, „Prvi markgrofski rat i Frankopani“, Modruški zbornik, Vol. 3 No 3, Modruš, 2009., str. $53-64$.

42 Robert KURELIĆ, Posljednji svjedok ubojstva: Frankopani i Celjski u petnaestome stoljeću, Povijesni prilozi, Vol. 50 No. 50, Zagreb, 2016., str. $205-229$. 
umjetnosti nikad nisu točno objasnili značenje te konzole ${ }^{43}$ ali treća takva nalazi se u frankapanskoj kapeli u katedrali grada Krka! ${ }^{44}$
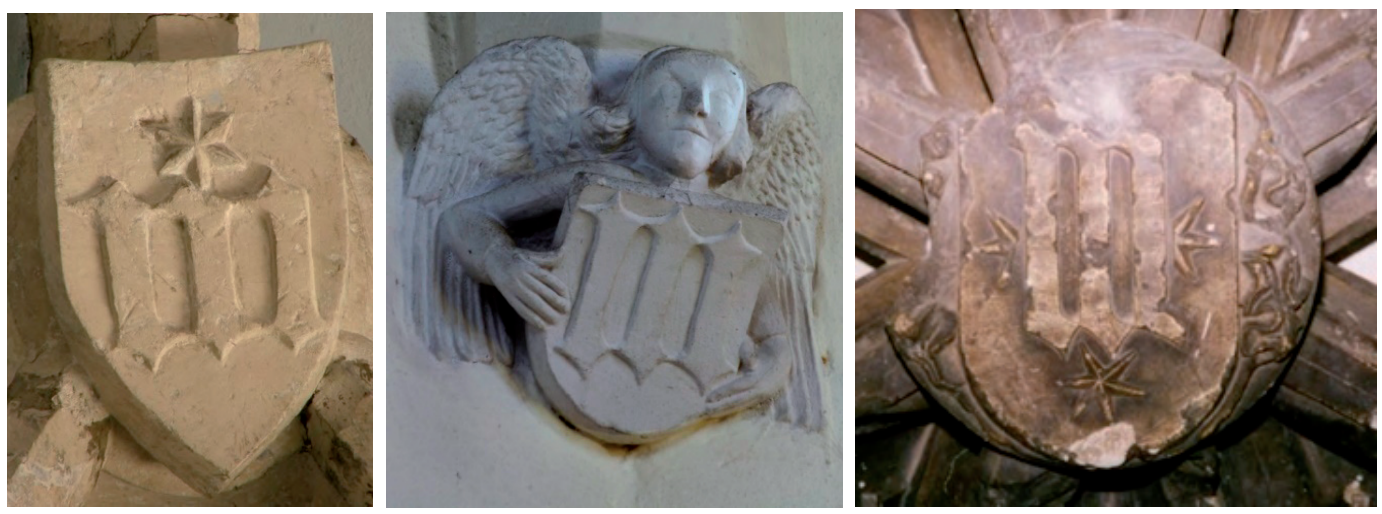

Slika 1. Gotičko „m“ iz frankapanske kapele u katederali, gotičko „m“ iz Svetog Martina na Muri i gotičko „m“ s grbom Celjskih iz crkve sv. Mihovila u Mihovljanu.

(preuzeto iz: Zdenko Balog, Graditeljska baština Hermana Celjskog i njezini odrazi u 15. stoljeću u zapadnoj Slavoniji, doktorska disertacija, Sveučilište u Zagrebu, 2012.)

Ovo je samo primjer koji nalazimo u Međimurju, a ima ih još diljem Celjskih i Frankapanskih posjeda.

\section{GRADNJA KAPELE SVETOG JERONIMA}

Kao što je već spomenuto, godine 1447. Fridrik Celjski završava gradnju kapele sv. Jeronima u Štrigovi. Ubrzo nakon toga, papa Nikola V. bulom blagoslivlja kapelu i hodočastilište u rodnom mjestu svetog Jeronima i jamči potpuni oprost grijeha svakom hodočasniku. ${ }^{45}$ I sam papa veli da je „plemeniti muž Friderik, grof Celja, Ortenbera, Zagorja te ban Kraljevine Slavonije, razmišljajući o vlastitom spasenju i želeći nagomilati veliko blago u nebeskim stvarima dao projektirati i

43 Međimurske crkve se mogu objasniti prvim imenom titulara (BALOG, Graditeljska baština, str. 150.), međutim, isto ne može vrijediti za kapelu Frankapana koja je posvećena sv. Barbari. Međutim, možda to $m$ predstavlja znamenitog Frankapana iz tog razdoblja, Martina!

44 BALOG, Graditeljska baština, str. 219; Isto, 229.

45 Bula se nalazi u: BEDEKOVIĆ, Natale solum, str. 175 - 176.; LUKINOVIĆ, Povijesni spomenici Zagrebačke biskupije sv. VII (1441. - 1465.), str. 128, dok. 126. 
sagraditi te svečano i bogato opremiti crkvu sv. Jeronima u Štrigovi Zagrebačke biskupije koja je nekad bila očinski dom samog sveca i u kojoj je bio othranjen i odgojen...".46 lako su mnogi povjesničari kasnije ovo shvatili kao neupitni argument tvrdnje da je upravo Štrigova rodno mjesto sv. Jeronima, papinu bulu prije svega treba promatrati kao dio općeg, ustaljenog odnosa Celjskih i papinske stolice. Jasno je i logično da su oni kao veliki crkveni dobročinitelji ${ }^{47}$ i priznati borci za kršćanstvo, ${ }^{48}$ u milosti papa. To uostalom možemo vidjeti i promatrajući ostale potvrde koje dobivaju tih godina. Primjerice, isti papa te godine dopušta i Ulriku i Fridriku Celjskom te njihovim družbenicima jesti meso, jaja i mliječne proizvode u vrijeme korizme. ${ }^{49}$ Isto tako, Fridriku i Ulriku Celjskom, kao i svim vojnicima koji su pratnja u njihovim pohodima dodjeljuje se potpuni oprost od grijeha $u$ slučaju smrti. ${ }^{50} \mathrm{Ni}$ ostalo plemstvo nije u ništa drugačijem odnosu s papom, pa tako vidimo da je od istog pape iste godine ispoštovana molba Frankapana da se poništi ujedinjavanje kapele svetog Mihovila u Dubovcu sa župnom crkvom sv. Jakoba u Mekušju, ${ }^{51}$ baš kao što su uslišane molba Frankapana oko dodjeljivanja uobičajenih oprosta crkvi sv. Leonarda u Lipovcu. ${ }^{52}$ Ovo su samo neki od primjera koji se vremenski gotovo u potpunosti poklapaju s papinom potvrdom vezanom uz kapelu sv. Jeronima u Štrigovi i oni nam jasno govore da su to zapravo uobičajeni obrasci ponašanja papa prema visokom plemstvu koje promiče, a na koncu i brani kršćanstvo.

Ubrzo nakon toga što je kapela izgrađena, godine 1448. Fridrik Celjski daruje kapeli i njenom rektoru Ivanu selište Leskovec, obavještava rektora da je dužan svake srijede služiti misu za svetog Jeronima, a svake subote za Mariju Magdalenu (zaštitnicu župe)..$^{53}$ Isprava nam je ostala sačuvana u latinskom prijepisu iz godine 1482., sastavljenom od strane Sigismunda Ernušta, biskupa Pečuha. ${ }^{54}$ Ono

46 Prijevod Marka Rašića preuzet iz: Dragutin FELETAR (ur.), Josip Bedeković. Knjiga o sv. Jeronimu, Iliriku i Međimurju, Zagreb - Čakovec, 2017., str. 171.

47 Vidi prethodno poglavlje i tamo spomenutu literaturu.

48 Nemojmo zaboraviti da Herman Celjski još 1396. sudjeluje u bitki na Nikopolju i da su kao najvažniji velikaši kraljevstva svakako naglašavali svoju ulogu branitelja kršćanstva u vrijeme osmanske ugroze.

49 LUKINOVIĆ, Povijesni spomenici Zagrebačke biskupije sv. VII (1441. - 1465.), str. 126, dok 124.

50 Isto, str. $126-127$, dok. 125.

51 Isto, str. 130, dok. 129.

52 Isto, str. 136, dok 135.

53 DL 32813; Marijana KORUNEK, Razvoj kompleksa pavlinskog samostana Blažene Djevice Marije i svih svetih u Šenkovcu (1376 - 1786) u svjetlu povijesnih i arheoloških istraživanja, doktorsa disertacija, Univerza v Mariboru, Maribor, 2015., str. 46.

54 Ernušti su tada i gospodari Međimurja: Nije ovo jedini slučaj iz srednjeg vijeka kada je primjetno uplitanje stranih biskupa. Međimurje pravno potpada pod Zagrebačku biskupiju, međutim, u praksi 
što nam je u toj ispravi posebno zanimljivo je i da se Štrigova navodi kao Strydo, što je prvi slučaj u dotadašnjoj povijesti. Također, saznajemo ime rektora iz 1448., Ivana, kao i ime kasnijeg rektora, Andrea, koji se spominje i u jednoj ispravi iz godine $1478 .{ }^{55} \mathrm{Uz}$ to se navodi opet kao utvrda koja uz Čakovec obilježava čitavo vlastelinstvo između Mure i Drave. Godine 1644. kapela je pripala pavlinima, a u prvoj polovici 18. stoljeća napravljena je nova crkva i oslikana predivnim freskama. ${ }^{56}$ Netom nakon završetka napisano je i već spominjano Bedekovićevo djelo Natale solum magni ecclesiae doctoris sancti Hieronymi in ruderibus Stridonis occultatum. U Štrigovi se od trenutka izgradnje kapele počinje štovati kult svetog Jeronima, i on se uz određene oscilacije zadržao do danas. Jasno je da prilikom bitnih događaja za mjesto i za samu jeronimsku tradiciju, poput izgradnje nove crkve posvećene patronu, oslikavanje iste freskama ili, u novije vrijeme, prevođenje važnog književnog djela o jeronimskoj tradiciji u Štrigovi, i kult posebno jača. Štrigova, unatoč gospodarskom stagniranju i nazadovanju kroz novi vijek, biva jedno od rijetkih međimurskih mjesta označenih na kartama, i to naznačena kao rodno mjesto svetog Jeronima. ${ }^{57}$ Jasno je dakle da je godina 1447 . i godina početka štovanja svetog Jeronima u Štrigovi, odnosno, početak štovanja možemo staviti još toliko unatrag koliko je Fridriku Celjskom točno trebalo da podigne spomenutu kapelu. Dok prije te godine ne nalazimo ni jedan izvor koji bi vezao kult sveza uz Štrigovu, od tada postaje poznata upravo po tome.

primjećujemo uplitanje drugih biskupa, kao i neplaćanje desetine u slučaju da osoba biskupa ne odgovara međimurskim gospodarima. Detaljnija istraživanja na tu temu upravo se provode.

55 DL 18143.

56 O pavlinima u Međiomurju vidi: KORUNEK, Razvoj kompleksa pavlinskog samostana Blažene Djevice Marije i svih svetih u Šenkovcu (1376 - 1786) u svjetlu povijesnih i arheoloških istraživanja.

57 Vidi: Lazar DEAK, Tabula Hungariae, Ingolstadt, 1528.; Matthias ZÜNDT, Nova totius Ungariae desciptio accurata diligens desumpta ex pluribus aliorum editis cosmographicis chartis et typis aereis incisa a Matthia Cynthio Norimbergensi Anno a Christo nato M.D. LXVII., 1567.; Giacomo CANTELLI, Parte della Schiavonia, overo Slavonia, aggiuntavi la Contea di Cillea e Windisch Mark abitate de popoli Slavini a Slavi, Rim, 1690.; Ovo su samo neki od primjera, na gotovo svim novovjekovnim kartama Štrigova se bilježi kao rodno mjesto svetog Jeronima. 


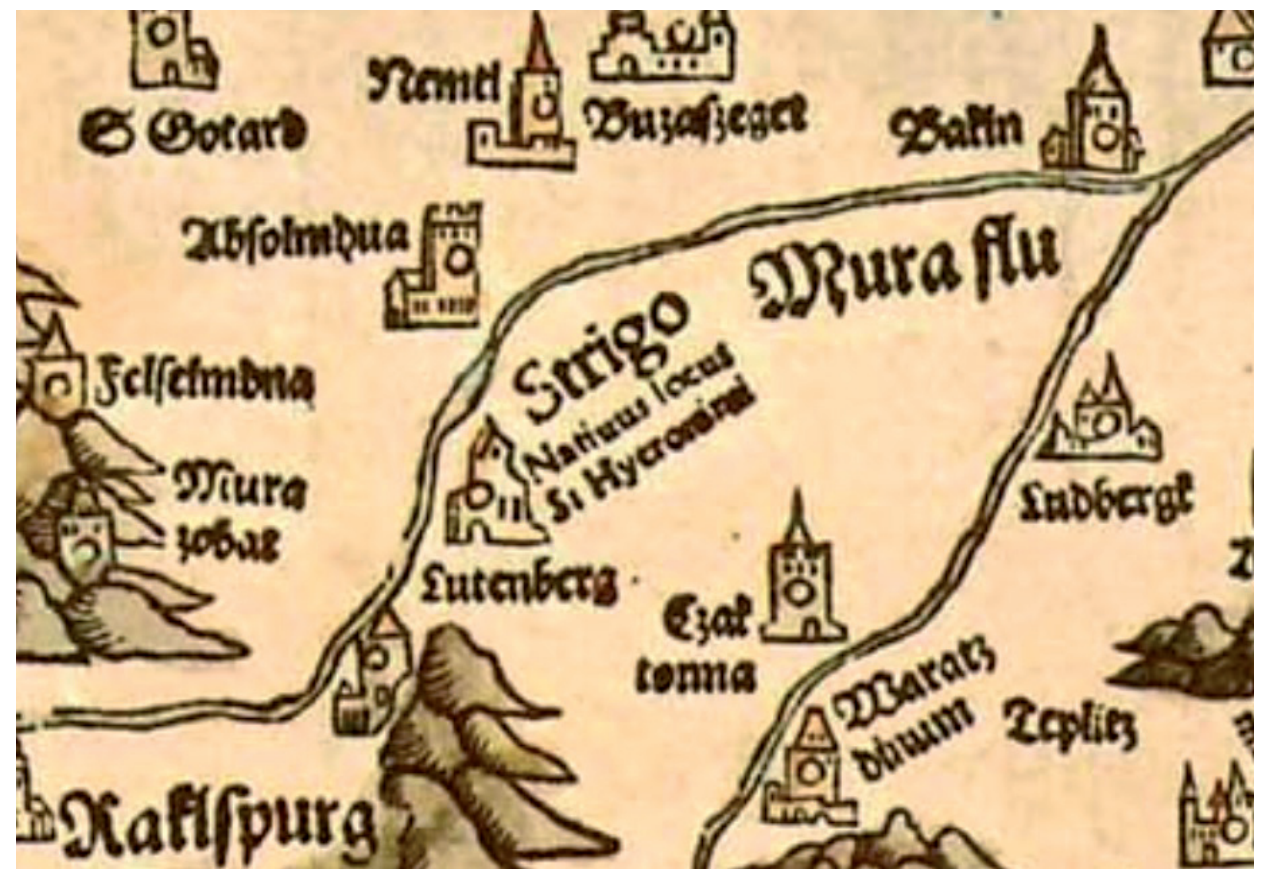

Slika 2. Štrigova na karti iz 1528. godine (Lazar DEAK, Tabula Hungariae, Ingolstadt, 1528.)

\section{KAKO SE VELIKI SVETAC NAŠAO U ŠTRIGOVI?}

Već smo zaključili da Fridrik Celjski, ne bi li ispravio svoja nedjela, gradi crkve i hodočastilišta diljem državine Celjskih. Zaključili smo i da su veze Celjskih i Frankapana jake čitavu prvu polovicu 15. stoljeća. Ostaje nam još pokušati otkriti tko je točno donio taj kult u Štrigovu. Poneki su autori pisali o benediktincima u Štrigovi, odnosno o benediktincima glagoljašima koji su tada došli u Štrigovu, a spominje se čak i benediktinska opatija. ${ }^{58}$ Svi su oni uglavnom krivo tumačili Bedekovića, koji sam kaže da ne zna koji su točno svećenici mogli doći u Štrigo-

58 Ignacije LIPNJAK, „Rad svećenstva za održavanje hrvatske svijesti u Međumurju posljednjih 10 godina prije oslobođenja“, Hrvati u borbama za oslobođenje sjevernih krajeva Jugoslavije: Međumurja, Prekmurja, Koruške i Štajerske (ur. Petar Jelavić), Zagreb, 1940, str. 20; Radoslav LOPAŠIĆ, Oko Kupe i Korane, Zagreb, 1895., str. 297; Vinko LAZOVINA, Dalmacija u hrvatskoj književnosti, Zagreb, 1936. str. 19; upozorava da Krčelić ne vjeruje tim navodima i da je davno prošlo vrijeme podizanja novih benediktinskih opatija. Vidi: Ivan OSTOJIĆ, „Benediktinci glagoljaši“, Slovo: časopis Staroslavenskoga instituta u Zagrebu, No 9-10, Zagreb, 1960., str. 31 - 32. 
vu, ali veli da su bili glagoljaši. ${ }^{59}$ Prema njemu je sjećanje o glagoljašima ostalo sačuvano u štrigovskoj mjesnoj ili pavlinskoj tradiciji, ali znamo da Bedeković nije prvi koji spominje glagoljaše u Štrigovi, već je to činio i Bombardi desetljećima prije. $^{60}$ lako su slični narativni izvori podložni greškama, izvrnutim sjećanjima i krivoj interpretaciji istih, postoji realna mogućnost da su zbilja u Štrigovu došli neki svećenici s Frankapanskih posjeda, ${ }^{61}$ koji bi odmah u imenu mjesta prepoznali sličnosti s antičkim Stridonom i koji bi čitavu tradiciju pokrenuli. Bedeković također veli da su isti svećenici, kako ih naziva, ${ }^{62}$ ne mogavši ostati, dragovoljno napustili to mjesto. Čini se da je on proučavajući Bombardija odlučio i sam ispitati lokalno stanovništvo i nakon što je naišao na potvrdu Bombardijevih navoda iste i zapisao. Koliko god takav slijed događaja imao smisla, ovdje prije svega moramo i oprezno naglasiti da to nije čvrsti argument i da nema (za sada) točne isprave koja bi nam objasnila porijeklo svećenstva pridošlog u Štrigovu.

Ono što bismo još spomenuli ovdje je i rastuća turska opasnost kroz 15. i 16. stoljeće, migracije, a shodno tome i promjene u strukturi stanovništva krajeva današnje sjeverne Hrvatske. ${ }^{63}$ Imamo jedan osmanski izvor koji opisuje upad

59 BEDEKOVIĆ, Natale solum, 306 - 307; Vidi i prijevod: FELETAR, Bedeković, str. 276 - 277.

60 Michaelis BOMBARDI, Topographia Magni Regni Hungariae, Sive Nobilissimae eius Ditionis, quam modo Hungariam dicimus : cum annexis Dalmatiae, Croatiae, Sclavoniae, Serviae, \& Bulgariae \&c. Regnis; tum etiam Transylvaniae, Valachiae, Moldaviae Provinciis, Gloriosißimo, \& vere Augusto eiusdem Assertori, Belli, Pacisque Arbitro Carolo VI. Romanorum Imperatori, Catholico, Apostolicoq[ue] Regi \&c. \&c. Inscripta, Beč, 1718, str. 93 - 95; Bombardi također spominje glagoljaše i opatiju, a donosi nam i transkript papine bule koju smo već spominjali.

61 Ili s bilo kojih drugih posjeda, svećenstvo je mobilno, a Celjski su izuzetno aktivni u vjerskom životu Kraljevstva. Konačno, upravo posjede koje su Celjski od Frankapana dobili u zalog nastanjuju i popovi glagoljaši.

62 Dakle, ne ističe da je riječ o benediktincima, tek spominje da se pričalo u narodu o opatiji.

63 O mobilnosti plemstva i migracijama uzrokovanim osmanskim nadiranjima bavi se Ivan Jurković: Ivan JURKOVIĆ: „Osmanska ugroza, plemeniti raseljenici i hrvatski identitet“, Povijesni prilozi, god. 25, br. 31, Zagreb, 2006., str. 39-69; isti, „Socijalni status i prisilni raseljenici podrijetlom iz hrvatskih plemićkih obitelji u zemljama njihovih doseoba za trajanja osmanske ugroze“, Zbornik Odsjeka za povijesne znanosti HAZU, vol. 23, Zagreb, 2005., str. 63-85; isti, „Osmanska ugroza, plemeniti raseljenici i hrvatski identitet“, Povijesni prilozi, god. 25, br. 31, Zagreb, 2006., str. 39-69; isti, „Turska opasnost i hrvatski velikaši - knez Bernardin Frankapan i njegovo doba", Zbornik Odsjeka za povijesne znanosti HAZU, vol. 17, Zagreb, 1999., str. 61-83. Osim navedenih radova, autor se bavio i pojedinačnim slučajevima ugroženih i raseljenih plemićkih obitelji: isti, „,Raseljena plemićka obitelj za osmanske ugroze: primjer Berislavića de Werhreka de Mala Mlaka (Dio prvi - Stjepan Berislavić Vrhrički i Malomlački)," Zbornik Odsjeka za povijesne znanosti HAZU, vol. 20, Zagreb, 2002., str. 125-164; isti, „Raseljena plemićka obitelj za osmanske ugroze: primjer Berislavića de Werhreka de Mala Mlaka (Dio drugi - Nasljednici Stjepana Berislavića tijekom 16. st.)“, Zbornik Odsjeka za povijesne znanosti HAZU, vol. 21, Zagreb, 2003., str. 119-180; isti, „Ugrinovići od Roga - Raseljena obitelj plemenitog roda Šubića Bribirskih za trajanja osmanske ugroze", Zbornik Odsjeka za povijesne znanosti HAZU, vol. 26, Zagreb, 2008., str. 71-85. 
Turaka u Međimurje $1479 .{ }^{64}$ Ono što je u izvoru za našu priču bitno, je da Ibn Kemal među stanovništvom Nedelišća, mjesta u Međimurju nedalko od Štrigove, prepoznaje one koji su „bili izašli iz kuće islama i zamijenili svjetlo vjere tamom nevjerništva, a u tom kraju se nastanili“.65. Jasno je da se u Međimurju već nalazi stanovništvo iz krajeva koje osvajaju i pustoše Turci, u ovom konkretnom slučaju je očito riječ o stanovništvu koje je na neko određeno vrijeme čak i prihvatilo islam. Nismo sigurno je li zbog sličnih razloga stanovništvo dolazilo već četrdesetih godina 15. stoljeća, pošto su ti procesi u najvećoj mjeri započeli padom Bosne 1463. i naslanjanjem Osmanskog Carstva na hrvatske zemlje. Ono što nam slični izvori mogu ponuditi je objašnjenje o popovima glagoljašima u narodnom sjećanju i narativnim izvorima 18. stoljeća, međutim, nije nemoguće da su glagoljaši stigli kasnije i da nemaju nikakve veze s dolaskom kulta sv. Jeronima. Međutim, iako promjene u strukturi stanovništva nemaju nužno veze s dolaskom kulta, lako je pretpostaviti da imaju veze s očuvanjem i jačanjem istog. Još Marko Marulić piše da u „Strigoi još postoji crkvica posvećena Jeronimu; podigli su je mještani da bi ostao trajan spomen na nj ondje gdje su doznali da je rođen, a sačuvao se i dio kuće za koju tvrde da je pripadala njegovim roditeljima“.66

\section{ZAKLJUČAK}

Čini se da definitivni odgovor o dolasku jeronimske tradicije u Štrigovu za sada nećemo dobiti, ali možemo za sigurnošću ustvrditi godine početka štovanja kulta i možemo ponuditi objašnjenje o dolasku samog kulta. Kako je jasno da se kult uz Štrigovu ne može vezati prije četrdesetih godina 15. stoljeća dolazimo i do zaključka da postoji tisućljetna rupa između života sveca i početka štovanja istog u međimurskoj utvrdi i trgovištu. Ustvrdili smo da je Fridrik Celjski, u najvećoj mjeri motiviran vječitim spasom duše, ${ }^{67}$ diljem svojih posjeda gradio crkve i hodočastilišta, te iste i darivao novim posjedima. Čini se da se Fridrikov trud za života isplatio, jer konačno, 3 godine prije smrti, upravo od pape Nikole V. dobiva

64 Riječ je o Ibn Kemalu, a analizu njegove kronike donosi: Dušanka BOJANIĆ, „Dve godine istorije Bosanskog krajišta (1479. i 1480.) - prema Ibn Kemalu“, Prilozi za orijentalnu filologiju 14-15, Sarajevo, 1969.str. 33-50.

65 Isto, str. 38.

66 MARULIĆ, Jeronim, str. 117.

67 Osim brojnih primjera gradnje crkava i hodočastilišta imamo i slučaj Fridrikovog darivanja tri selišta u Lovrečanu župnicima Svetog Martina pod Oštrcem, uz uvjet da svake nedjelje služe misu za oproštenje grijeha njemu i njegovim nasljednicima. Vidi: LUKINOVIĆ, Povijesni spomenici Zagrebačke biskupije sv. VII (1441. - 1465.), str. 195, dok 190. 
potpuni oprost u smrtnom času, te odrješenje od pridržanih grijeha!68 Utvrdili smo i da papa vrlo rado pomaže vjerno i vrijedno plemstvo koje aktivno djeluje na gradnji i obrani kršćanske Europe. Također, ponudili smo i konkretne smjernice za konačni odgovor o kultu svetog Jeronima, koje još treba potvrditi daljnjim istraživanjima Celjsko - Frankapanske veze i mobilnosti svećenstva u sredini 15. stoljeća.

Pretpostavka da je priča o glagoljašima izmišljena ne drži vodu. Ako bi kod Bedekovića i pronašli razlog u njegovoj naglašenoj svijesti o vlastitoj pripadnosti, ne možemo i za Bombardija, koji je istu tvrdnju iznio prije i kojeg Bedeković koristi kod pisanja svojeg djela. lako vidimo da je problem daleko kompleksniji od samog naslova ovog rada, do pronalaska novih izvora ovakav nam naslov nudi i najobjektivnije rješenje.

\section{IZVORI}

1/ ARHIVSKA GRAĐA:

Magyar Országos Levéltár, Diplomatikai Levéltar

\section{DIPLOMATIČKE ZBIRKE}

1/ Georgius FEJÉR, Codex diplomaticus Hungariae ecclesiasticus ac civilis, 5, 1., Budimpešta, 1829.

2/ Nagy IMRE: Anjoukori okmánytár. Codex diplomaticus Hungaricus Andegavensis. IV. (1340-1346), Budapest, 1884.

3/ Ivan KUKULJEVIĆ SAKCINSKI, Jura Regni Croatiae, Dalmatiae et Slavoniae, Zagreb, 1861.

4/ Andrija LUKINOVIĆ, Povijesni spomenici Zagrebačke biskupije sv. VI(1421 - 1440.), VII(1441. - 1465.), Zagreb 1994. - 2004.

5/ Tadija SMIČIKLAS, Codex diplomaticus regni Croatiae, Dalmatiae et Slavoniae. Diplomatički zbornik kraljevine Hrvatske, Dalmacije i Slavonije, sv. 2-18, Zagreb, 1904.-1990.

\section{NARATIVNI IZVORI}

1/ Josip BEDEKOVIĆ, Natale solum magni ecclesiae doctoris sancti Hieronymi in ruderibus Stridonis occultatum, Bečko Novo Mjesto, 1752.

2/ Michaelis BOMBARDI, Topographia Magni Regni Hungariae, Sive Nobilissimae eius Ditionis, quam modo Hungariam dicimus : cum annexis Dalma-

68 Isto, str. 208, dok 201. 
tiae, Croatiae, Sclavoniae, Serviae, \& Bulgariae \&c. Regnis; tum etiam Transylvaniae, Valachiae, Moldaviae Provinciis, Gloriosißimo, \& vere Augusto eiusdem Assertori, Belli, Pacisque Arbitro Carolo VI. Romanorum Imperatori, Catholico, Apostolicoq[ue] Regi \&c. \&c. Inscripta, Beč, 1718

\section{KARTOGRAFSKI IZVORI}

1/ Giacomo CANTELLI, Parte della Schiavonia, overo Slavonia, aggiuntavi la Contea di Cillea e Windisch Mark abitate de popoli Slavini a Slavi, Rim, 1690.

2/ Lazar DEAK, Tabula Hungariae, Ingolstadt, 1528.

3/ Matthias ZÜNDT, Nova totius Ungariae desciptio accurata diligens desumpta ex pluribus aliorum editis cosmographicis chartis et typis aereis incisa a Matthia Cynthio Norimbergensi Anno a Christo nato M.D. LXVII., 1567.

\section{LITERATURA}

1/ Vesna BADURINA STIPČEVIĆ, „Legenda o svetom Jeronimu u hrvatskoglagoljskom Petrisovu zborniku", Radovi : Radovi Zavoda za hrvatsku povijest Filozofskoga fakulteta Sveučilišta u Zagrebu, Vol.47 No.1, Zagreb, 2016., str. 337-350.

2/ Zdenko BALOG, Graditeljska baština Hermana Celjskog i njezini odrazi u 15. stoljeću u zapadnoj Slavoniji, doktorska disertacija, Filozofaski fakultet u Zagrebu, Zagreb, 2012.

3/ Dušanka BOJANIĆ, „Dve godine istorije Bosanskog krajišta (1479. i 1480.) prema Ibn Kemalu“, Prilozi za orijentalnu filologiju 14-15, Sarajevo, 1969.str. 33-50.

4/ Frane BULIĆ, Stridon (Grahovo Polje u Bosni) rodno mjesto svetog Jeronima. Rasprava povjesno geografska, Sarajevo, 1920.

5/ Csánki DEZSŐ, Magyarország történelmi földrajza a Hunyadiak korában, 3. kötet, Zalävarmegye, Várai és erősségei, S(z)trigo - online izdanje: https:// www.arcanum.hu/hu/online-kiadvanyok/Csanki-csanki-dezso-magyarorszag-tortenelmi-foldrajza-a-hunyadiak-koraban-1/iii-kotet-62BB/zalavarmegye-62DC/varai-es-erossegei-6300/

6/ Dragutin FELETAR (ur.), Josip Bedeković. Knjiga o sv. Jeronimu, Iliriku i Međimurju, Zagreb - Čakovec, 2017.

7/ John V.A. FINE, „The Slavic Saint Jerome“, Harvard Ukrainian Studies 22, Harvard, 1998., str. $101-113$

8/ Josip FLORSCHÜTZ, „Stridon i Zrin“, Vjesnik Arheološkog muzeja u Zagrebu Vol 6 Br1, Zagreb, 1902., str. $87-98$. 
9/ Anđela FRANČIĆ, „Ojkonim Štrigova kroz stoljeća“, Folia onomastica Croatica, vol , br 21, Zagreb, 2012., str. 37 - 58.

10/ Anđela HORVAT, Spomenici arhitekture i likovnih umjetnosti u Međimurju, Čakovec, 2010.

11/ Ines IVIĆ, „Jerome Comes Home: The Cult of Saint Jerome in Late Medieval Dalmatia", Hungarian Historical Review 5, no. 3, Budimpešta, 2016., str. $1-27$.

12/ Ivan JURKOVIĆ: „Osmanska ugroza, plemeniti raseljenici i hrvatski identitet“, Povijesni prilozi, god. 25, br. 31, Zagreb, 2006., str. 39-69; isti, „Socijalni status i prisilni raseljenici podrijetlom iz hrvatskih plemićkih obitelji u zemljama njihovih doseoba za trajanja osmanske ugroze", Zbornik Odsjeka za povijesne znanosti HAZU, vol. 23, Zagreb, 2005., str. 63-85

13/ Ivan JURKOVIĆ, „Osmanska ugroza, plemeniti raseljenici i hrvatski identitet", Povijesni prilozi, god. 25, br. 31, Zagreb, 2006., str. 39-69; isti, „Turska opasnost i hrvatski velikaši - knez Bernardin Frankapan i njegovo doba“, Zbornik Odsjeka za povijesne znanosti HAZU, vol. 17, Zagreb, 1999., str. 61-83.

14/ Ivan JURKOVIĆ, „Raseljena plemićka obitelj za osmanske ugroze: primjer Berislavića de Werhreka de Mala Mlaka (Dio prvi - Stjepan Berislavić Vrhrički i Malomlački)," Zbornik Odsjeka za povijesne znanosti HAZU, vol. 20, Zagreb, 2002., str. 125-164.

15/ Ivan JURKOVIĆ, „Raseljena plemićka obitelj za osmanske ugroze: primjer Berislavića de Werhreka de Mala Mlaka (Dio drugi - Nasljednici Stjepana Berislavića tijekom 16. st.)", Zbornik Odsjeka za povijesne znanosti HAZU, vol. 21, Zagreb, 2003., str. 119-180.

16/ Ivan JURKOVIĆ, „Ugrinovići od Roga - Raseljena obitelj plemenitog roda Šubića Bribirskih za trajanja osmanske ugroze", Zbornik Odsjeka za povijesne znanosti HAZU, vol. 26, Zagreb, 2008., str. 71-85.

17/ Lajos KISS, Földrajzi nevek etimológiai szótára, Budimpešta, 1980.

18/ Marijana KORUNEK, Razvoj kompleksa pavlinskog samostana Blažene Djevice Marije i svih svetih u Šenkovcu (1376 - 1786) u svjetlu povijesnih i arheoloških istraživanja, doktorsa disertacija, Univerza v Mariboru, Maribor, 2015.

19/ Vanda KRAFT SOIĆ, „OTPIS INOCENTA IV. SENJSKOM BISKUPU (1248.) POD PATRONATOM SV. JERONIMA I. Senjski privilegij iz godine 1248.", Croatica Christiana periodica, Vol 40 No 77, Zagreb, 2016. str. $1-23$.

20/ Vanda KRAFT SOIĆ, „OTPIS INOCENTA IV. SENJSKOM BISKUPU (1248.) POD PATRONATOM SV. JERONIMA / II. Povijesni usud glagoljice i začetci jeronimske tradicije", Croatica Christiana periodica, Vol 40 No 78, Zagreb, 2016. str. $17-37$. 
21/ Robert KURELIĆ, Posljednji svjedok ubojstva: Frankopani i Celjski u petnaestome stoljeću, Povijesni prilozi, Vol.50 No.50, Zagreb, 2016., str. 205 - 229.

22/ Robert KURELIĆ, „Pregled povijesti grofova Celjskih“, Historijski zbornik 59, Zagreb, 2006., str. 201-216.

23/ Robert KURELIĆ, „"Prvi markgrofski rat" i Frankopani“, Modruški zbornik, Vol 3 No 3, Modruš, 2009., str. $53-64$

24/ Vinko LAZOVINA, Dalmacija u hrvatskoj književnosti, Zagreb, 1936.

25/ Ignacije LIPNJAK, „Rad svećenstva za održavanje hrvatske svijesti u Međumurju posljednjih 10 godina prije oslobođenja", Hrvati u borbama za oslobođenje sjevernih krajeva Jugoslavije: Međumurja, Prekmurja, Koruške i Štajerske (ur. Petar Jelavić), Zagreb, 1940.

26/ Radoslav LOPAŠIĆ, Oko Kupe i Korane, Zagreb, 1895.

27/ Wilhelm LETTENBAUER, „Zur entstehung des glagolitischen alphabets“, Slovo : časopis Staroslavenskoga instituta u Zagrebu, No 3, Zagreb, 1953., str. $35-50$.

28/ Marko MARULIĆ, „Životopis sv. Jeronima prezbitera koji je sastavio Marko Marulić, uz dodatak čudesa koja o njemu pripovijeda Ćiril, biskup nazaretski, prikazanih u sažetijem obliku“, Latinska manja djela II, Split, 2011.

29/ Ivan OSTOJIĆ, „Benediktinci glagoljaši“, Slovo : časopis Staroslavenskoga instituta u Zagrebu, No 9-10, Zagreb, 1960., str. $14-42$.

30/ István PETROVICS, „King Mathias and the Towns of Realm“, Analele Banatului , s.n., Arheologie - istorie, XXI, 2013, str. 283 - 294.

31/ Ivan SRŠA, „Crtice o međimurskom srednjovjekovlju“, Kaj:časopis za književnost, umjetnost i kulturu 50, Zagreb, 2017., str. 75-101.

32/ Luka ŠPOLJARIĆ, „Venecijanski skjavoni i povijesno-liturgijska knjižica u čast sv. Jeronima Ilira iz 1498. godine" Colloquia Maruliana ..., 27. (27.), Split, 2018., str. 43-71.

33/ Zoran TURK, "Srednjovjekovno plemstvo Međimurja“, Radovi Zavoda za znanstveni rad HAZU Varaždin, br 28, 2017., str. 305-352.

34/ Julia VERKHOLANSTEV, The Slavic Letters of st. Jerome. The History of the Legend and Its Legacy, or, How the Translator of the Vulgate Became an Apostle of the Slavs, DeKalb, 2014. 


\section{SAŽETAK \\ KAPELA SV. JERONIMA U ŠTRIGOVI \\ - HODOČASTILIŠTE ZA SPAS DUŠE FRIDRIKA CELJSKOG}

Ponovnim izdanjem poznatog djela Josipa Bedekovića zaživjelo je pitanje kulta svetog Jeronima u Štrigovi, kao i staro pitanje rodnog mjesta velikog sveca. To je pitanje intrigiralo razne autore već stoljećima, a mi kroz rad dajemo odgovor o dizanju kulta svetog Jeronima u srednjovjekovnoj Štrigovi, navodnom mjestu njegova rođenja, i pokušavamo objasniti inicijalne faze procesa koji je tako uključio Štrigovu u veliku grupu mjesta duž granice rimskih provincija Panonije i Dalmacije. Godine 1447. Fridrik Celjski gradi kapelu posvećenu svetom Jeornimu i osniva hodočastilište, za koje dobiva i papinsku bulu koja prepoznaju Štrigovu kao Jeronimovo rodno mjesto. Tek se od tog trenutka Štrigova kroz narativne i kartografske izvore dovodi u taj kontekst i ta se tradicija uz osciliacije održala do danas. Novovjekovni nam narativni izvori spominju popove glagoljaše u Štrigovi, koji bi bez sumnje prepoznali sličnost imena Štrigove i rimskog Stridona. Mi kroz rad nudimo odgovore o potencijalnoj ulozi glagoljaša u jačanju kulta sv. Jeronima u Štrigovu i pokretanju tradicije o Štrigovi kao rodnom mjestu Jeronima.

Ključne riječi: Štrigova; Međimurje; Celjski; Frankapani; sv. Jeronim; glagoljaši. 


\section{SUMMARY \\ CHAPEL OF ST. JEROME IN ŠTRIGOVA - SOUL SAVING PILGRIMAGE SITE OF FREDERICK OF CILLI}

Scholarly discussion on various issues related to St Jerome and his cult, including the age-old question of his birthplace, was recently revitalized following the publication of the translation of Josip Bedeković's eighteenth-century monograph on the 'Illyrian' Doctor of the Church. This question has indeed intrigued various authors for quite some time, and we will try to offer some answers with respect to the rise of St Jerome's cult in medieval Štrigova, a purported place of his birth, and to explain initial phases of the process which eventually included Štrigova into the relatively large group of places along the borders of Roman provinces of Pannonia and Dalmatia. In 1447 Freiderick of Cilli built a chapel dedicated to Saint Jerome in Štrigova and later strove to establish it as a pilgrimage site. He soon received a papal bull which recognized Štrigova as the birthplace of the Saint. Only after these mid-fifteenth-century events took place, Štrigova started to appear in numerous narrative and cartographic sources as his birthplace, a tradition still cherished today. Narrative sources tell us that Štrigova was one of the centres of Glagolitic priests, who would have surely made the connection between the toponym Štrigova and Roman Stridon and we will, thus, focus on the role of this group in the establishment of both Jerome's cult in Štrigova and the place's identification with Jerome's hometown of Stridon.

Key Words: Štrigova; Međimurje; Counts of Cilli; Frankapan counts; Saint Jerome; glagolitic priests. 
